\title{
Purification and Biosynthesis of a Spore Coat Protein in Bacillus megaterium QM B 1551
}

\author{
By TOMIO ICHIKAWA, ${ }^{*}+$ KAZUYA YAMANISHI, \\ KAZUHITO WATABE, TSUTOMU NISHIHARA AND \\ MASAOMI KONDO \\ Faculty of Pharmaceutical Sciences, Osaka University, Suita, Osaka, Japan
}

(Received 3 September 1981; revised 21 December 1981)

\begin{abstract}
A spore coat protein of Bacillus megaterium QM B 1551 was purified from an SDS-DTT extract of lysozyme-digested spores using Sephadex, DEAE-cellulose chromatography and polyacrylamide disc gel electrophoresis. The molecular weight of the protein was approximately 12000 . It constituted about $13 \%$ of spore dry weight and was rich in lysine, aspartic acid, glycine and alanine residues. The sum of these four amino acids constituted $53.9 \%$ of the total amino acids. Small amounts of phosphorus and sugar were detected, but no amino sugar. The protein was synthesized in the cytosol of sporulating mother cells at $t_{3}$, and accumulated on the forespores.
\end{abstract}

\section{INTRODUCTION}

The bacterial spore coat, the outermost spore structure, is a spore-specific constituent and makes the first contact with elements in the environment, such as germinants, germicides, UV light or heat. It has been suggested that the spore coat may play an important role in germination, dormancy or resistance.

Many investigators (Aronson \& Fitz-James, 1976; Goldman \& Tipper, 1978; Mitani \& Kadota, 1976; Munoz et al., 1978; Uchida \& Kadota, 1976; Watabe et al., 1975) have reported that spore-specific components extracted from spore coats with SDS and DTT consist mainly of a protein with a molecular weight of approximately 10000 . The spore coat protein comprises $25-80 \%(w / w)$ of the mature spore and is one of the few sporulationspecific antigens described to date. Characterization of the spore coat protein is a necessary prerequisite for determining its contribution to dormancy.

The purpose of this investigation was to isolate and identify the spore coat protein of $B$. megaterium QM B 1551 and to determine the time of its synthesis in sporulating cells.

\section{METHODS}

Strain and preparation of spores. Bacillus megaterium QM B 1551 was cultivated in Schaeffer's medium with shaking at $37^{\circ} \mathrm{C}$ for $48 \mathrm{~h}$. Cells were collected by centrifugation and washed repeatedly with water. Vegetative cells were removed completely by this procedure so that more than $99 \%$ of the remaining structures were spores, which were stored lyophilized.

Spore fractionation and purification of spore coat protein. Spores were suspended to give $5 \mathrm{mg}$ dry $\mathrm{wt} \mathrm{ml}^{-1}$ in $100 \mathrm{~mm}$-sodium borate, $\mathrm{pH} 10.0$, containing $0.1 \mathrm{M}-\mathrm{NaCl}, 0.5 \%(\mathrm{w} / \mathrm{v})$ SDS and $0.03 \mathrm{M}-\mathrm{DTT}$. The mixture was incubated at $37^{\circ} \mathrm{C}$ for $2 \mathrm{~h}$ and centrifuged at $12000 \mathrm{~g}$ for $20 \mathrm{~min}$. The supernatant solution (Sup-1) was filtered through a membrane filter (pore size $0.45 \mu \mathrm{m}$ ). Treated spores (S-1) were suspended to give $1 \mathrm{mg} \mathrm{dry} \mathrm{wt} \mathrm{ml}^{-1}$ in Tris $/ \mathrm{HCl}, \mathrm{pH} 8.0$, treated with lysozyme $\left(100 \mu \mathrm{g} \mathrm{m}^{-1}\right)$ at $37^{\circ} \mathrm{C}$ for $60 \mathrm{~min}$, and centrifuged (Sup-2). The pelleted material was washed with water and lyophilized (S-2). The lyophilized sediment was extracted with

$\dagger$ Present address: National Institute of Nutrition, Shinjuku ku, Tokyo, Japan.

Abbreviations: DTT, dithiothreitol; SDS, sodium dodecyl sulphate. 


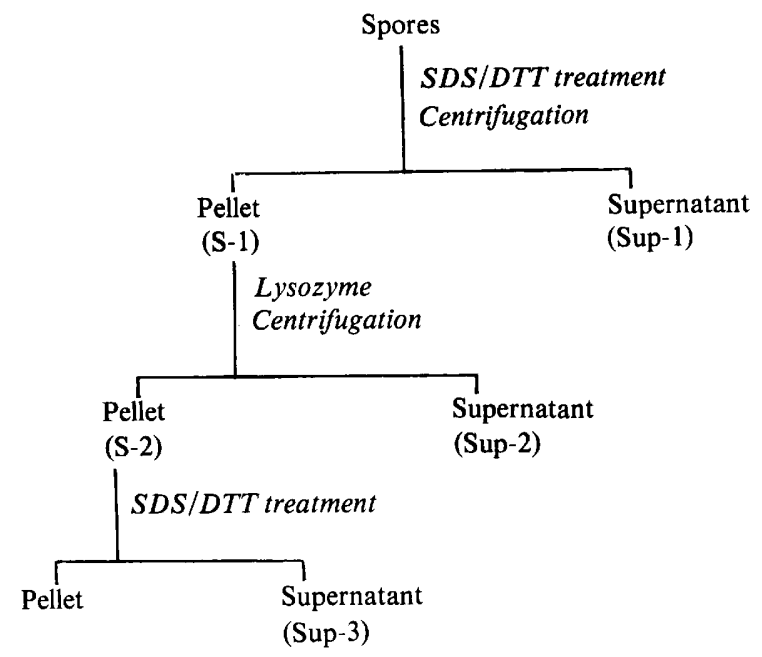

Fig. 1. Procedure for the fractionation of spores.

$100 \mathrm{~mm}$-sodium borate, $\mathrm{pH} 10 \cdot 0$, containing $0.5 \% \mathrm{SDS}, 0.03 \mathrm{~m}$-DTT and $0.1 \mathrm{M}-\mathrm{NaCl}$ at $37^{\circ} \mathrm{C}$ for $2 \mathrm{~h}$, then centrifuged. The supernatant solution was filtered through a membrane filter (Sup-3). The procedure is summarized in Fig. 1.

The supernatant fractions were used for the purification of the spore coat protein by means of Sephadex G-200, Sephadex G-100 and DEAE-cellulose column chromatography with 100 mm-sodium borate, pH $10 \cdot 0$, containing $0.1 \%$ SDS, each used according to the manufacturer's instructions. The material was stored in 100 mM-sodium borate, $\mathrm{pH} 10 \cdot 0$, containing $0.1 \%$ SDS and then further purified by disc gel electrophoresis (see below).

Preparation of forespore and mother cell cytoplasm. This was done according to the method of Fujita et al. (1977).

Electron microscopy. Thin sections were prepared as described previously (Nishihara et al., 1980) and observed with an electron microscope (JEOL, JEM-120,80 kV).

Disc gel electrophoresis. For PAGE, $10 \%$ polyacrylamide disc gels containing $1.0 \%$ SDS were used. Samples were incubated in solution A $(2 \%$ SDS, $2 \%(\mathrm{v} / \mathrm{v}) \beta$-mercaptoethanol, $2 \%(\mathrm{v} / \mathrm{v})$ phenol red, $8 \mathrm{M}$-urea in $100 \mathrm{~mm}$-borate buffer, $\mathrm{pH} \mathrm{10.0)}$ at $45^{\circ} \mathrm{C}$ for $60 \mathrm{~min}$, and $20 \mu \mathrm{l}$ of the mixture were applied to disc gels. Electrophoresis was carried out at $5 \mathrm{~mA}$ per tube for $3 \mathrm{~h}$ at $\mathrm{pH} 10 \cdot 0$, and gels were stained with Coomassie blue (Weber \& Osborn, 1969).

Preparation of anti-spore coat protein serum. Antibodies were prepared using $2.5 \mathrm{~kg}$ white female rabbits and the following schedule. Antigen (spore coat protein) $(1.5 \mathrm{mg}$ ) was mixed with an equal volume of Freunds' complete adjuvant and injected into the footpad of the rabbit at zero time. Three weeks following initial injection, the rabbit was injected with a further $0.5 \mathrm{mg}$ of a similar antigen preparation. One week later the final $(0.5 \mathrm{mg})$ injection was given. The rabbit was bled from the peripheral vein of the ear on consecutive days one week following the final injection.

Determination of spore coat antigen by immunodiffusion assay. Antispore coat protein serum was mixed with $2 \%(\mathrm{w} / \mathrm{v})$ agar containing $20 \mathrm{~mm}$-Tris/ $\mathrm{HCl}, \mathrm{pH} 7.9,20 \mathrm{~mm}-\mathrm{NaCl}$ and $2 \mathrm{~mm}-\mathrm{EDTA}$. The mixture was poured into a test tube $(50 \times 3 \mathrm{~mm})$ to a height of $25 \mathrm{~mm}$. A sample $(3 \mu \mathrm{l})$ containing spore coat antigen was poured into the test tube, which was then incubated at $25^{\circ} \mathrm{C}$ for $24 \mathrm{~h}$. The distance from the top of the agar/antigen mixture to the precipitation band was measured. The amount of spore coat antigen in a sample was estimated from a calibration curve using variable amounts of spore coat protein. The distance was linear with respect to the logarithm of concentration of spore coat protein $(0.5$ to $1.0 \mu \mathrm{g}$ in $3 \mu \mathrm{l})$.

Analysis. Amino acid composition was determined with an amino acid analyser (JEOL, JLC-5AH) after hydrolysis of samples with $6 \mathrm{M}-\mathrm{HCl}$ at $105^{\circ} \mathrm{C}$ for $20 \mathrm{~h}$ in a sealed tube. The amount of half-cystine was determined after oxidation (Moor, 1963). Phosphorus, sugar and amino sugar were determined by the methods of Chen et al. (1956), Dubois et al. (1956), and Rondle \& Morgan (1966), respectively. Protein was determined by the Lowry method. 

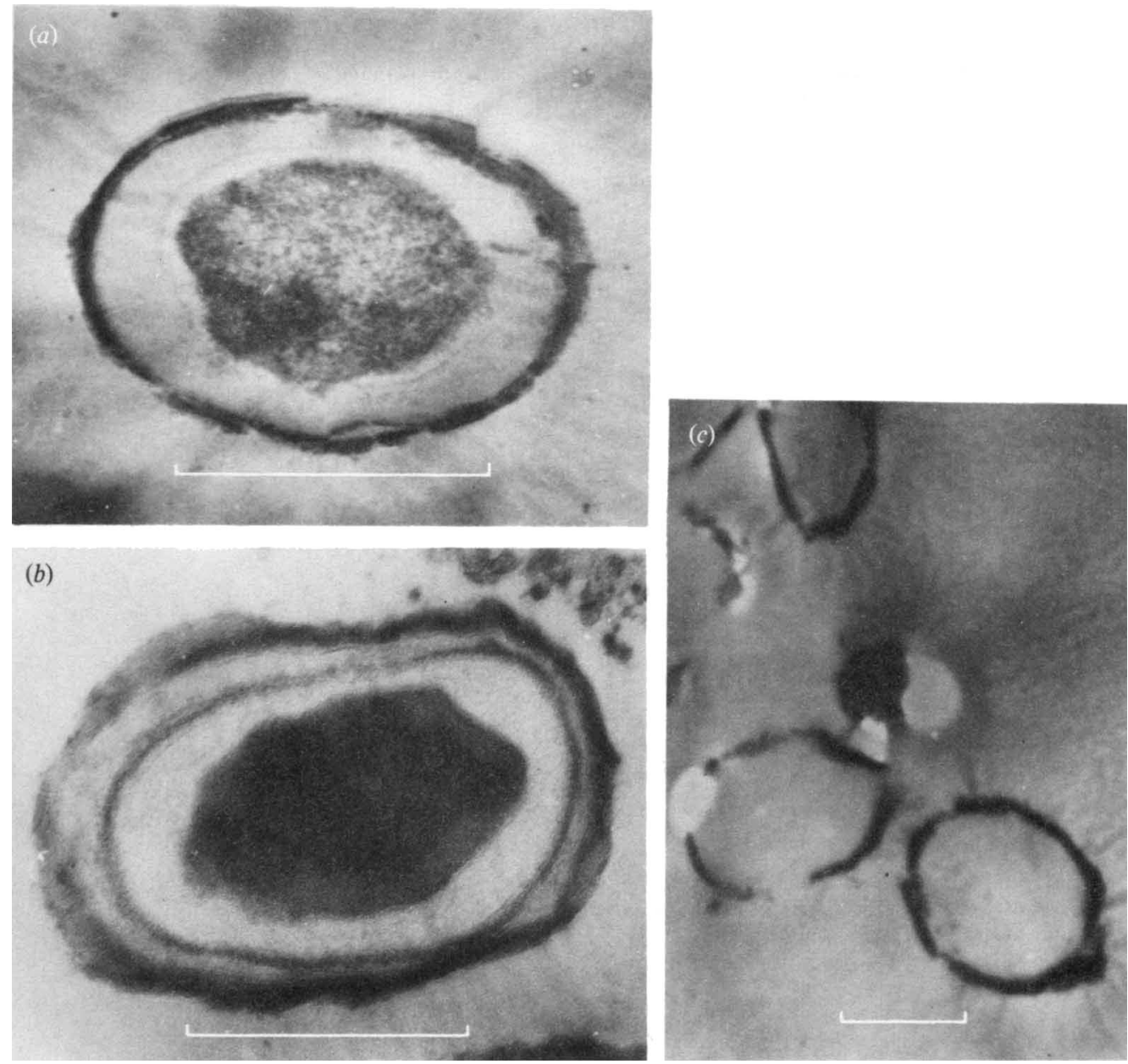

Fig. 2. Thin-sectioned spores and spore fractions. (a) Intact spores; (b) SDS/DTT-treated spores (fraction S-1); (c) fraction S-2. The bar markers represent $1 \mu \mathrm{m}$.

\section{RES ULTS}

\section{Components extracted with $S D S, D T T$ and $\mathrm{NaCl}$}

Spores were successively treated with SDS/DTT, lysozyme, and again with SDS/DTT, as described in Methods. SDS/DTT-treated spores are sensitive to lysozyme (Vary, 1973). Electron microscopic examination of fraction S-2 (Fig. $2 c$ ) and the distribution of spore coat antigen in each fraction (Table 3; Dormant spores) suggested that Sup-3 contained extracted spore coat protein. The substances present in this second SDS/DTT extract (Sup-3) represented $20 \%$ of spore dry weight (Table 1), of which $85.5 \%$ was protein. Electrophoresis showed that Sup-3 was heterogeneous, with several major bands of protein. The predominant band had an $R_{F}$ of 0.75 . This portion of the gel was extracted with borate buffer and its protein content was determined. The extracted spore coat protein represented $75 \%$ of the protein content of the SDS/DTT extract (Sup-3), and corresponded to $13 \%$ of the protein present in whole spores. 
Table 1. Relative dry weight and protein content of spore fractions

Spores were fractionated as described in Methods. Values in parentheses represent protein as a percentage of dry wt.

$\begin{array}{ll}\text { Fraction } & \begin{array}{c}\text { Percentage of } \\ \text { dry wt }\end{array} \\ \text { Intact spore } & 100 \\ \text { Sup-1 } & 17.0(75 \cdot 8) \\ \text { S-1 } & 83.0 \\ \text { S-2 } & 30.8 \\ \text { Sup-3 } & 20.0(85 \cdot 5) \\ \text { Residue } & 10.8\end{array}$

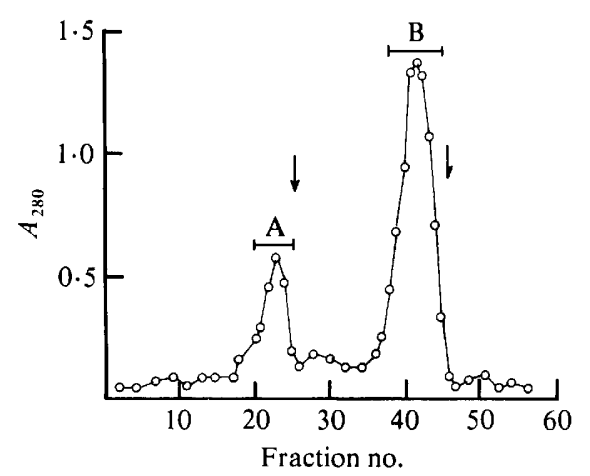

Fig. 3. Sephadex G-200 column chromatography of Sup-3. Sup-j was applied to a column $(2 \cdot 1 \times$ $82 \mathrm{~cm}$ ) of Sephadex G-200;3.1 ml fractions were collected. Fractions A and B are indicated. Arrow, Blue dextran; half arrow, cytochrome $c$.

\section{Purification of the spore coat protein}

When Sup-3 was fractionated by column chromatography on Sephadex G-200 $(2 \cdot 1 \times$ $82 \mathrm{~cm}$ ), using $100 \mathrm{~mm}$-borate buffer, $\mathrm{pH} 10 \cdot 0$, containing $0 \cdot 1 \%$ SDS, two peaks (fractions A and B) were obtained (Fig. 3). Fraction B was concentrated, applied to a Sephadex G-100 column $(1.6 \times 100 \mathrm{~cm})$ and eluted as a single peak of protein with $100 \mathrm{~mm}$-borate buffer, $\mathrm{pH} 10 \cdot 0$, containing $0.1 \%$ SDS. Appropriate fractions were pooled, applied to a DEAE-cellulose column $(1.8 \times 1.4 \mathrm{~cm})$ and eluted with $100 \mathrm{~mm}$-Tris/HCl, pH 7.6, containing $0.1 \%$ SDS with a linear gradient of $0-1 \cdot 0-\mathrm{M}-\mathrm{NaCl}$. Only a single peak, eluting at approximately $0.4 \mathrm{M}-\mathrm{NaCl}$, was detected by the measurement of $A_{280}$. The peak fractions were collected and dialysed against $100 \mathrm{~mm}$-borate buffer, $\mathrm{pH} 10 \cdot 0$, containing $0.1 \%$ SDS, and subjected to SDS-PAGE. The section of the gel corresponding to the major Coomassie

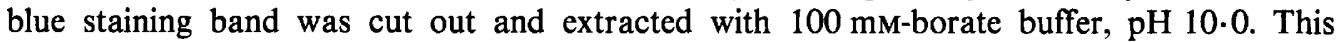
extracted spore coat protein showed only a single band in SDS-PAGE, which had an apparent molecular weight of 12000 when compared with standard proteins.

\section{Amino acid composition of the spore coat protein}

The amino acid composition of the spore coat protein is given in Table 2. The protein contains large amounts of lysine, aspartic acid, glycine and alanine, with these four amino acids constituting $53.9 \%$ of the total amino acids. The protein contains little methionine or histidine. The phosphorus and sugar contents of the protein were 0.71 and $1.36 \mu \mathrm{mol} \mathrm{mg}^{-1}$, respectively, but amino sugar was not detected. 
Table 2. Amino acid composition of the spore coat protein and Sup-3

Values for amino acids are molar percentages and for phosphorus, sugar and hexosamine, $\mu \mathrm{g}(\mathrm{mg} \text { protein })^{-1}$.

$\begin{array}{lcc}\text { Component } & \text { Sup-3 } & \begin{array}{c}\text { Spore coat } \\ \text { protein }\end{array} \\ \text { Lys } & 10.4 & 12.3 \\ \text { His } & 1 \cdot 7 & 1 \cdot 1 \\ \text { Arg } & 8 \cdot 8 & 5 \cdot 3 \\ \text { Asp } & 14 \cdot 8 & 15.6 \\ \text { Thr } & 4.9 & 4.9 \\ \text { Ser } & 6 \cdot 0 & 7.6 \\ \text { Glu } & 6.2 & 4.5 \\ \text { Pro } & \text { Trace } & \text { Trace } \\ \text { Gly } & 11.7 & 12.5 \\ \text { Ala } & 10.7 & 13.5 \\ \text { Val } & 3.5 & 4.4 \\ \text { Met } & 2.4 & 0.9 \\ \text { Ile } & 4.5 & 5.0 \\ \text { Leu } & 7.4 & 7.9 \\ \text { Phe } & 2.1 & 2.1 \\ \text { Tyr } & 9.6 & 2.6 \\ \text { Cys (half) } & - & 2.6 \\ \text { Phosphorus } & 3.5 & 2.2 \\ \text { Sugar } & 5.7 & 24.6 \\ \text { Hexosamine } & 22.6 & 0.0 \\ & & \end{array}$

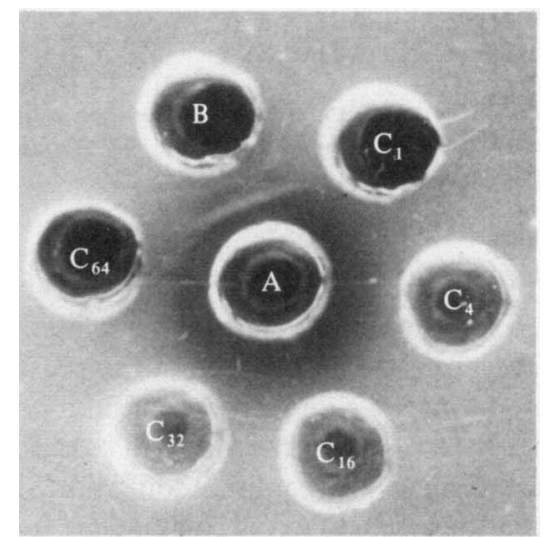

Fig. 4. Immune double diffusion of vegetative cell cytoplasm and purified spore coat protein. A, antispore coat serum; B, purified spore coat protein; C, vegetative cell cytoplasm (numbers indicate dilution ratio).

\section{Antigenic localization of the spore coat protein within the spore}

When purified spore coat protein was reacted with spore coat protein antiserum, only a single precipitation band was observed, suggesting homogeneity (Fig. 4). Each fraction obtained from spores was reacted with spore coat protein anti-serum. Three of the fractions yielded precipitate bands, showing that each contained spore coat antigen (Table 3). Quantitative determination of spore coat antigen in each fraction showed that Sup-3 contained $10.6 \%$ of the spore coat antigen of the whole spore, while Sup-1 and Sup- 2 each contained only $1.9 \%$ of the spore coat antigen of the whole spore (Table 3 ). 
Table 3. Amounts of spore coat antigen in each spore and forespore fraction

$\begin{array}{ccc}\text { Cell type } & \text { Fraction } & \begin{array}{c}\text { Spore coat antigen } \\ \text { (percentage of spore dry wt) }\end{array} \\ t_{6} \text { (forespores) } & \text { Sup-1 } & 13.5 \\ & \text { Sup-2 } & 10 \cdot 5 \\ & \text { Sup-3 } & 0.4 \\ t_{9} & \text { Sup-1 } & 9.8 \\ & \text { Sup-2 } & 5.7 \\ \text { Dormant spores } & \text { Sup-3 } & 8.9 \\ & \text { Sup-1 } & 1.9 \\ & \text { Sup-2 } & 1.9 \\ & \text { Sup-3 } & 10.6\end{array}$

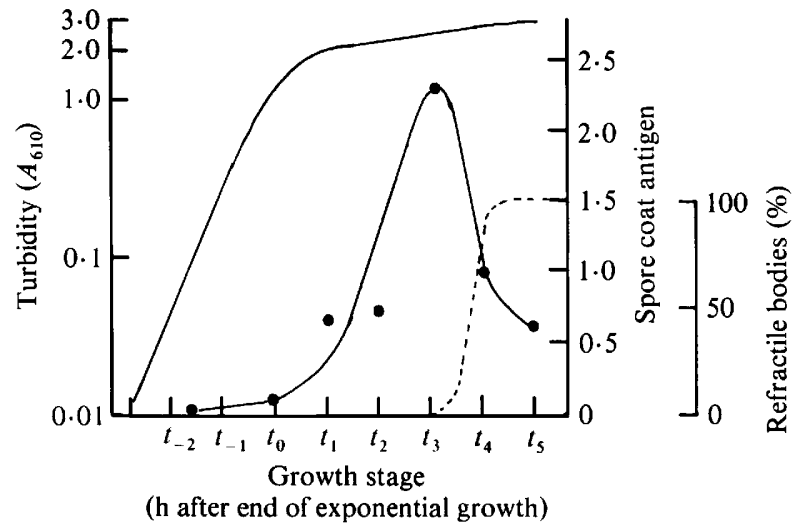

Fig. 5. Occurrence of the spore coat antigen in the mother cell fraction of the sporulating cell (percentage of spore dry wt) (O). - $\longrightarrow$, Turbidity; ----, frequency of refractile bodies. Sample preparation and assay are described in Methods.

\section{Spore coat antigen in sporulating cells and forespores}

Cells were cultivated in double-strength Schaeffer's medium and harvested at intervals. Mother cell cytoplasm and forespores were prepared in the presence of the protease inhibitor phenylmethylsulphonylfluoride (1 mM), as described by Fujita et al. (1977). Sup-1 and Sup-3 were prepared from forespores by the same procedure as used for spores. The distribution of the spore coat antigen was determined using immunodiffusion (Fig. 5). Cytosolic spore coat antigen was maximal at $t_{3}$ and then decreased. Before $t_{3}$, no forespores were detected; they began to appear at $t_{3}$. In forespores at $t_{6}$, the spore coat antigen was mostly present in Sup-1 and Sup-2 (Table 3), but as maturation progressed, the spore coat antigen transferred from Sup-1 to Sup-3.

\section{DISC USSION}

The purification of spore coat proteins from B. megaterium QM B 1551 has not previously been reported. We describe here the purification of the major protein of the spore coat from SDS/DTT extracts of lysozyme-digested spores. The origin of the protein was determined to be the spore coat both by electron microscopy and by the distribution of the spore coat antigen in each fraction of spores.

The protein, of approximate molecular weight 12000 , constitutes about $13 \%$ of the dry weight of the spore and is rich in lysine, aspartic acid, glycine and alanine residues. Proteins of 
molecular weight 8000-12000 were extracted earlier from spores of B. subtilis and B. cereus (Aronson \& Fitz-James, 1976; Pandy \& Aronson, 1979). Mitani \& Kadota (1976) and Uchida \& Kadota (1976) independently observed that $B$. subtilis spores contain a protein with a molecular weight of 10000 as the main component of the spore coat, and Watabe et al. (1975) reported that $B$. thiaminolyticus spores contain a protein of molecular weight 10000 . In B. cereus (Aronson, 1981), the major structural protein of the spore coat is a precursor of 65000 , which is synthesized in the sporulating cells. About $40 \%$ of this precursor is converted to spore coat monomer of molecular weight 13000 .

In B. subtilis (Munoz et al., 1978), a precursor spore coat protein with a molecular weight of 25000 is made initially at $t_{1}$ of the sporulation cycle and is converted to the mature spore coat protein with a molecular weight of 18500 at $t_{2}-t_{3}$. Jenkinson et al. (1981) reported that in $B$. subtilis, an alkali-soluble spore coat protein with a molecular weight of 12000 is synthesized at an early stage of sporulation $\left(t_{2}\right)$, and a 36000 molecular weight protein is synthesized at a very late stage $\left(t_{6}\right)$. In our study, the synthesis of a spore coat protein began at $t_{1}$ in the cytoplasm of sporulating cells. The amount of the protein increased in the mother cell cytoplasm until $t_{3}$ and then decreased. This might indicate that the newly synthesized spore coat protein was deposited in the forespores and then translocated to the inner part of the spore coat. Our result does not indicate the presence of a precursor of the spore coat protein, since only one antigenic species was ever observed (Table 3). These facts might indicate processing of the spore coat protein following synthesis, leading to accumulation and maturation in the forespore.

The synthesis of the proteins in sporulating cells requires clarification. Further investigations are clearly warranted.

Dr Barry P. Rosen is thanked for valuable discussions and for reading the manuscript.

\section{REFERENCES}

Aronson, A. I. \& Fitz-James, P. C. (1976). Structure and morphogenesis of the bacterial spore coat. Bacteriological Reviews 40, 360-402.

Aronson, A. I. (1981). Synthesis of Bacillus cereus spore coat protein. Journal of Bacteriology 145, 541-547.

Chen, P. S., Toribara, T. Y., JR \& WARner, H. (1956). Microdetermination of phosphorus. Analytical Chemistry 28, 1756-1758.

Dubois, M., Gilles, K. A., Hamilton, J. K., Reber, P. A. \& SMITH, F. (1956). Colorimetric method for determination of sugar and related substances. Analytical Chemistry 28, 350-356.

Fujita, Y., Ramaley, R. \& Freese, E. (1977). Location of and properties of glucose dehydrogenase in sporulating cells and spores of Bacillus subtilis. Journal of Bacteriology 132, 282-292.

Goldman, R. C. \& TIPPER, D. J. (1978). Bacillus subtilis spore coats: complexity and purification of a unique polypeptide component. Journal of Bacteriology 135, 1091-1106.

Jenkinson, H. F., SAwyer, W. D. \& Mandelstam, J. (1981). Synthesis and order of assembly of spore coat protein in Bacillus subtilis. Journal of General Microbiology 123, 1-16.

Mitani, T. \& Kadota, H. (1976). Chemical features of spore coat of Bacillus subtilis. Journal of General and Applied Microbiology 22, 51-63.

Moor, S. (1963). On the determination of cysteine as cysteic acid. Journal of Biological Chemistry 238, 235-237.

Munoz, L., Sadale, Y. \& Dol, R. H. (1978). Spore coat protein of Bacillus subtilis. Journal of Biological Chemistry 253, 6694-6701.

Nishihara, T., ICHIKaWA, T. \& Kondo, M. (1980). Location of elements in ashed spores of Bacillus megaterium. Microbiology and Immunology 24, 495-506.

Pandy, N. K. \& Aronson, A. I. (1979). Properties of the Bacillus subtilis spore coat. Journal of Bacteriology 137, 1208-1218.

Rondle, C. M. \& Morgan, W. T. J. (1966). The determination of glucosamine and galactosamine. Biochemical Journal 61, 586-589.

UCHIDA, A. \& KADOTA, H. (1976). Detection of spore coat protein of Bacillus subtilis. Agricultural and Biological Chemistry 40, 1349-1354.

VARY, J. C. (1973). Germination of Bacillus megaterium spores after various extraction procedures. Journal of Bacteriology 116, 797-802.

WATABE, K., KakIUCHI, Y. \& Kondo, M. (1975). Solubilization of coat protein from Bacillus thiaminolyticus spores. Microbios 12, 221-224.

WEBER, K. \& OsBORN, M. (1969). The reliability of molecular weight determined by dodecyl sulfatepolyacrylamide gel electrophoresis. Journal of Biological Chemistry 244, 4406-4412. 